\title{
Preparation of Functional Monomers as Precursors of Bioprobes from a Common Styrene Derivative and Polymer Synthesis
}

\author{
Riho Hayama ${ }^{1}$, Tetsuo Koyama ${ }^{1}$, Takahiko Matsushita ${ }^{1,2}{ }^{\mathbb{D}}$, Ken Hatano ${ }^{1,2}$ \\ and Koji Matsuoka 1,2,*iD \\ 1 Division of Material Science, Graduate School of Science and Engineering, Saitama University, Sakura, \\ Saitama 338-8570, Japan; ri11270825@gmail.com (R.H.); koyama@fms.saitama-u.ac.jp (T.K.); \\ takahiko@fms.saitama-u.ac.jp (T.M.); khatano@fms.saitama-u.ac.jp (K.H.) \\ 2 Medical Innovation Research Unit (MiU), Advanced Institute of Innovative Technology (AIIT), \\ Saitama University, Sakura, Saitama 338-8570, Japan \\ * Correspondence: koji@fms.saitama-u.ac.jp; Tel.: +81-48-858-3099 \\ Academic Editor: Lothar Elling \\ Received: 28 September 2018; Accepted: 2 November 2018; Published: 4 November 2018

\begin{abstract}
CM-Str (4-(Chloromethyl)styrene) was used as a useful starting material for the construction of a series of functional monomers. Substitution of the chlorine to the corresponding azide was performed, and the reduction of the azide proceeded smoothly to afford an aminostyrene, which was used as a common precursor for the preparation of functional monomers. Condensation of the amine with a fluorophore, biotin and carbohydrate was accomplished. Among the monomers, a carbohydrate monomer was polymerized with or without acrylamide as a model polymerization to yield the corresponding water-soluble glycopolymers, and biological evaluations of the glycopolymers for a lectin, and wheat germ agglutinin (WGA), were carried out on the basis of the fluorescence change of tryptophan in the WGA.
\end{abstract}

Keywords: styrene; glycopolymers; radical polymerization; lectins; fluorescence spectrometry

\section{Introduction}

Although oligosaccharides and their derivatives are of great interest as bioactive compounds in various research areas, the affinities of the carbohydrate moieties are not so high [1,2]. In nature, the oligosaccharide chains in glycoconjugates play a role and have high specificities in biological events, and a recent report suggested that the affinities of oligosaccharide chains in glycolipids and glycoproteins were enhanced by the self-assembly of glycoconjugates, which display multivalent-type clusters. Much attention has been paid to the formation of synthetic glycoclusters by covalent bonds, and glycodendrimers [3-5] and glycopolymers [6-10] have been successfully developed. In our ongoing studies of glycopolymers, we have reported a conventional method for the preparation of a glycopolymer by means of Huisgen cycloaddition as a key reaction for the synthesis of monomers and glycopolymers [11]. The efficient assembly of carbohydrate moieties induced an enhancement of the affinities for a lectin on the basis of carbohydrate-protein interactions [12-15].

The functionalization of monomers as bioprobes is highly attractive and of great importance in order to evaluate their biological phenomena. For example, fluorogenic monomers are useful in order to evaluate an interaction between carbohydrate molecules and a glyscosidase [16]. In addition to the fluorogenic compounds, the biotin-avidin interaction is also an important biological event and a useful biological tool for biochemical and biomedical uses $[17,18]$. In this paper, we describe an alternative pathway for the convenient preparation of a glycomonomer and functional monomers 
using a commercially available and inexpensive reagent, 4-chloromethylstyrene (CM-Str), as a starting material. The further transformation of the glycomonomer into corresponding glycopolymers is reported. In addition to the syntheses, the results of the biological evaluations of the glycopolymers with $N$-acetyl-D-glucosamine (NAG) residues for wheat germ agglutinin (WGA) [19] as a model lectin are also described.

\section{Results and Discussion}

The utilization of 4-(chloromethyl)styrene $\mathbf{1}$ (CM-Str) as a starting material for the preparation of a series of functionalized monomers was examined in order to construct polymeric bioprobe families. We previously reported a convenient synthesis of glycomonomers using CM-Str $\mathbf{1}$ as a starting material by means of the Huisgen cycloaddition reaction [20-23] and polymer syntheses [11]. In this paper, alternative preparations of a glycomonomer and other useful functional monomers are described.

\subsection{Conversion of 4-(Chloromethyl)styrene into an Amine as a Common Precursor}

Commercially available CM-Str $\mathbf{1}$ as a versatile precursor for an azide compound was used as a convenient starting material, and the conversion of the azide 2 (AZ-Str) [24] into the corresponding amine derivative by the Staudinger reaction was performed. Scheme 1 summarizes the preparation of aminostyrene derivative 3 (AMN-Str) [25] from CM-Str 1. The $S_{N} 2$ replacement of the chloride of CM-Str 1 was performed by an azide anion in a polar aprotic solvent at a slightly high temperature to afford the corresponding AZ-Str 2 in 90\% yield [11]. The Staudinger reaction of AZ-Str 2 with triphenylphosphine (TPP) afforded the corresponding CM-Str 3 in 96\% yield. Two-step-conversion from 1 to 3 was reported and the yield was moderate (63\% in two steps) [25]. In our case, the yield was improved ( $86 \%$ in two steps) by the replacement of a solvent from benzene to THF in Scheme 1(ii).

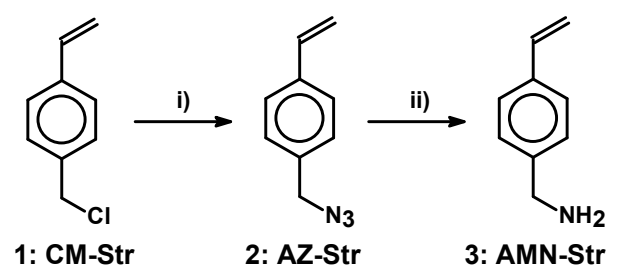

Scheme 1. Reagents and conditions: (i) $\mathrm{NaN}_{3}, \mathrm{DMF}, 80^{\circ} \mathrm{C}, 1 \mathrm{~h}$, (ii) $\mathrm{TPP}, \mathrm{H}_{2} \mathrm{O}, \mathrm{THF}, 0^{\circ} \mathrm{C}, 2.5 \mathrm{~h}$.

\subsection{Synthetic Conversion of the Amine into Functionalized Monomers}

Given the success of the simple preparation of AMN-Str 3, which had a highly reactive primary amino function, we next turned our attention to the applicability of AMN-Str 3 as a common precursor for the synthesis of functional monomers. Scheme 2 shows the chemical conversion of AMN-Str 3 into useful monomers with a styrene moiety. Commercially available acid chloride of a dansyl derivative was first used to introduce fluorescent moieties into the synthetic polymer. Thus, the dansylation of AMN-Str 3 with dansyl chloride in the presence of an acid scavenger proceeded smoothly to afford the dansylated styrene derivative 4 (DSL-Str) [26] as a fluorogenic monomer in $76 \%$ yield. Structural elucidations were performed by a combination of IR, ${ }^{1} \mathrm{H}-\mathrm{NMR}$ and elemental analyses. An alternative functionalization of AMN-Str 3 was performed using a biotin as an attractive biomolecule in order to obtain a strong interaction between an avidin and the biotin [18]. Thus, the D-(+)-biotin was coupled with AMN-Str 3 using typical condensing reagents [27] such as 1-ethyl-3-(3-dimethylaminopropyl)carbodiimide hydrochloride (EDC), $N, N^{\prime}$-diisopropyl carbodiimide (DIC), and (benzotriazol-1-yloxy)tris(dimethylamino)phosphonium hexafluorophosphate (BOP). All of the coupling reagents unfortunately produced unsuccessful or poor results due to a solubility problem of the biotin derivatives. The results are summarized in Table 1. Since well-known condensing reagents did not work in this coupling reaction, we decided to use 4-(4,6-dimethoxy-1,3,5-triazin-2-yl)-4-methylmorpholinium chloride (DMT-MM), which was 
introduced by Kunishima et al. [28]. The biotin was treated with AMN-Str 3 in the presence of DMT-MM to afford the corresponding amide 5 (BTN-Str) in $91 \%$ yield.

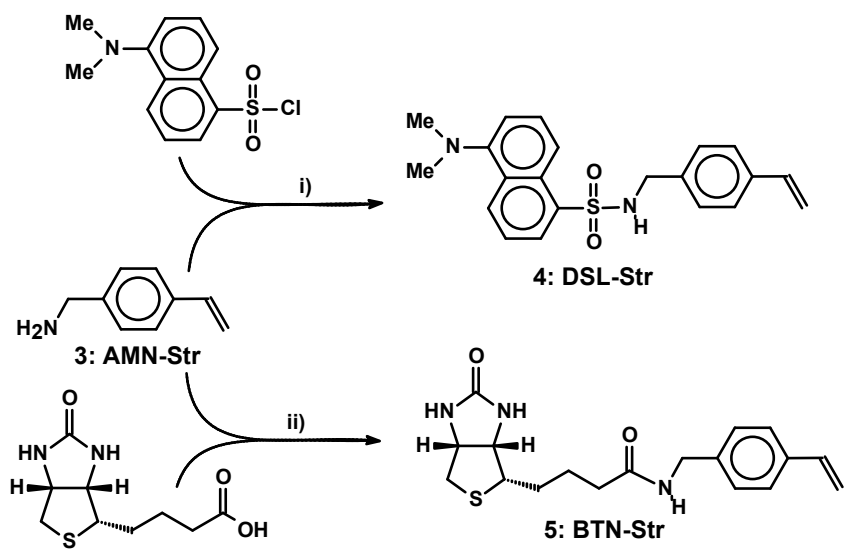

Scheme 2. Reagents and conditions: (i) Dansyl chloride, $\mathrm{Et}_{3} \mathrm{~N}$, dichloromethane (DCM), rt, $5.5 \mathrm{~h}$, (ii) biotin, DMT-MM, DMF, rt, $1.5 \mathrm{~h}$.

Table 1. Results of the coupling reaction of AMN-Str 3 and biotin.

\begin{tabular}{ccccc}
\hline Reagent & Solvent & Temp $\left({ }^{\circ} \mathbf{C}\right)$ & Time (h) & Yield (\%) \\
\hline DIC & DMF & Rt & on & 0 \\
EDC & DMF & Rt & 5 & 0 \\
BOP & $\mathrm{CH}_{3} \mathrm{CN}$ & $\mathrm{Rt}$ & 3 & $36^{1}$ \\
BOP & $\mathrm{DMF}$ & $\mathrm{Rt}$ & 1.5 & $17^{1}$ \\
DMT-MM & $\mathrm{DMF}$ & $\mathrm{Rt}$ & 2 & 91 \\
\hline \multicolumn{5}{c}{}
\end{tabular}

\subsection{Preparation of a Carbohydrate Monomer}

Although the effective conversion of the aminostyrene 3 (AMN-Str) into functional monomers was accomplished, the further transformation of the amine was required in order to produce carbohydrate monomers, which are bioactive compounds and are recognized by various lectin molecules. A schematic diagram of the preparation of a glycomonomer 10 (NAG-Str) is shown in Scheme 3. Since the hydrophilicity of the styrene moiety was low, we decided to use a polyethyleneoxy alcohol, which has the appropriate hydrophilicities as an aglycon moiety. Thus, a known oxazoline derivative 6 [29] was treated with 2,2'-(ethylenedioxy)diethanol in the presence of camphorsulfonic acid (CSA) [30] to yield a monoalcoholic glycoside 7 as a yellow syrup in $76 \%$ yield. An anomeric configuration of glycoside 7 was determined using ${ }^{1} \mathrm{H}-\mathrm{NMR}$ spectra. The results revealed a signal assignable to $\mathrm{H}-1$ at $\delta 4.77$ as a doublet with $J_{1,2}=8.60 \mathrm{~Hz}$, which was confirmed to be a $\beta$-glycoside. The primary alcohol had to be oxidized to carboxylic acid before the coupling reaction of the glycoside with the amine 3 . Thus, 2,2,6,6-tetramethylpiperidine 1-oxyl free radical (TEMPO)-mediated oxidation [31] of the alcohol 7 was carried out to produce the desired carboxylic acid 8, which was directly used for the next step due to the production of an inseparable byproduct in the reaction. We therefore estimated the yield of the oxidation to be approximately $46 \%$. Freshly prepared carboxylic acid 8 and the amine 3 were applied for a DMT-MM-mediated coupling reaction, and the reaction proceeded smoothly to produce the corresponding styrene derivative 9 as a colorless syrup in $78 \%$ yield after chromatographic purification. Structural elucidation of product 9 was performed by means of ${ }^{1} \mathrm{H}$ - and ${ }^{13} \mathrm{C}-\mathrm{NMR}$ spectroscopic analyses. Since the appearance of aromatic ring proton signals at $7.39 \mathrm{ppm}$ and $7.27 \mathrm{ppm}$ in 9 was observed in the ${ }^{1} \mathrm{H}-\mathrm{NMR}$ results, the progress of the coupling reaction was confirmed. In addition to the ${ }^{1} \mathrm{H}-\mathrm{NMR}$ results, the combined results of the ${ }^{13} \mathrm{C}-\mathrm{NMR}$ and HMQC experiments also supported the formation of $\mathbf{9}$. The removal of the acetyl protection in 9 
was performed by using the Zemplén method [32] to afford NAG-Str 10 as a water-soluble material in $99 \%$ yield.

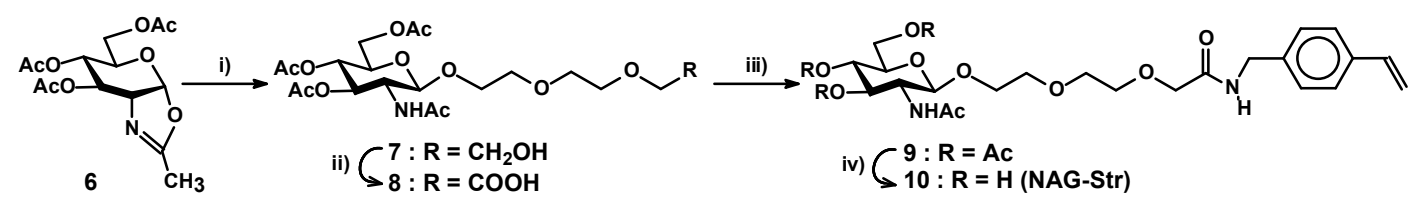

Scheme 3. Reagents and conditions: (i) 2,2'-[ethane-1,2-diylbis(oxy)]di(ethan-1-ol), $\mathrm{CSA}, \mathrm{ClCH}_{2} \mathrm{CH}_{2} \mathrm{Cl}$, $90{ }^{\circ} \mathrm{C}, 1 \mathrm{~h}$, (ii) aq. $\mathrm{NaHCO}_{3}, \mathrm{KBr}$, TEMPO, trichloroisocyanuric acid, acetone, $0{ }^{\circ} \mathrm{C}, 20 \mathrm{~min}$, then rt, $4.5 \mathrm{~h}$; (iii) AMN-Str 3, DMT-MM, DCM, rt, 3.5 h; (iv) NaOMe, $\mathrm{MeOH}, \mathrm{rt}, 1.5 \mathrm{~h}$.

\subsection{Polymerization of a Glycomonomer by Means of Radical Polymerization}

The synthetic conversion of AMN-Str 3 into functional monomers was successfully demonstrated, and our next objective was the chemical conversion of the monomers into the corresponding polymers. In our synthetic study of glycoclusters, radical polymerization was applied for the synthetic assembly of carbohydrate epitopes. This type of monomer had not hitherto been used in our study. Thus, the $\mathrm{N}$-acetyl-D-glucosaminyl monomer 10 (NAG-Str) was used as a model monomer for the preparation of glycopolymers, as shown in Scheme 4. The polymerization ability of NAG-Str $\mathbf{1 0}$ was first evaluated by radical polymerization without a comonomer in aqueous media at room temperature. NAG-Str 10 underwent homopolymerization to yield white powdery 11a in 71\% yield after dialysis against water followed by lyophilization. A successful polymerization protocol was applied for the preparation of copolymers of NAG-Str $\mathbf{1 0}$ and acrylamide, and the results of the copolymerizations are summarized in Table 2. The weight-average molecular weights $(\overline{M w})$ of the glycopolymers were estimated by size exclusion chromatography in $0.3 \mathrm{M}$ aqueous $\mathrm{NaCl}$ solution. From the weight-average molecular weight $(\overline{M w})$ of glycopolymer 11a, the degree of polymerization was estimated to be 653 . The polymer compositions of glycopolymers $\mathbf{1 1 b}, \mathbf{1 1} \mathrm{c}$ and $\mathbf{1 1 d}$ were estimated on the basis of the ${ }^{1} \mathrm{H}-\mathrm{NMR}$ results. All of the polymers (11a-11d) had water-soluble abilities and appropriate molecular weights as estimated by size-exclusion chromatography (SEC) analyses.



Scheme 4. Reagents and conditions:

(i) acrylamide, ammonium persulfate (APS), tetramethylethylenediamine (TEMED) rt.

Table 2. Results of polymerizations of NAG-Str 10 with or without acryl amide (AAm).

\begin{tabular}{ccccccccc}
\hline $\begin{array}{c}\text { Monomer } \\
\text { Ratio } \\
\text { 10:AAm }\end{array}$ & Polymer & Time (h) & Solvent & $\begin{array}{c}\text { Total } \\
\text { Yield } \\
\text { (\%) }\end{array}$ & $\begin{array}{c}\text { Polymer } \\
\text { Composition } \\
\text { x:y:n }\end{array}$ & $\begin{array}{c}\text { Sugar } \\
\text { Content } \\
\text { (wt\%) }\end{array}$ & $\overline{\mathbf{M w}}{ }^{3}$ (kDa) & $\mathbf{D}^{\mathbf{4}}$ \\
\hline $1: 0$ & $\mathbf{1 1 a}$ & 69 & $\mathrm{H}_{2} \mathrm{O}$ & 71 & $1: 0: 6.5 \times 10^{2}$ & 100 & 315 & 1.13 \\
$1: 4$ & $\mathbf{1 1 b}$ & 24 & $\mathrm{H}_{2} \mathrm{O}$ & 81 & $1: 4: 6.2 \times 10^{2}$ & 63 & 472 & 1.01 \\
$1: 10$ & $\mathbf{1 1 c}$ & 24 & $\mathrm{H}_{2} \mathrm{O}$ & 99 & $1: 11: 1.5 \times 10^{2}$ & 38 & 183 & 2.52 \\
$1: 20$ & $\mathbf{1 1 d}$ & 24 & $\mathrm{H}_{2} \mathrm{O}$ & 90 & $1: 22: 1.5 \times 10^{2}$ & 24 & 297 & 1.34 \\
\hline
\end{tabular}

${ }^{1}$ Total yields were calculated on the basis of the quantities of monomers used. ${ }^{2}$ Polymer compositions of sugar unit:acrylamide unit were estimated on the basis of the ${ }^{1} \mathrm{H}-\mathrm{NMR}$ results. ${ }^{3}$ The weight-average molecular weights were estimated by size-exclusion chromatography in $0.3 \mathrm{M}$ aq NaCl solution using a Shodex GF-510HQ column. Calibration curves were obtained using pullulan standards $(5.9,11.8,22.8,47.3,112,212,404$, and $788 \mathrm{kDa}$, Shodex P-82). ${ }^{4}$ Dispersity $(D)$ were calculated on the basis of $(\overline{M w}) /(\overline{M n})$. 


\subsection{Biological Evaluations of the Glycopolymers for Lectin}

Once the synthetic assembly of sugar moieties using polymer chemistry was accomplished, we turned our attention to the biological properties of the glycopolymers. Interactions between glycopolymers 11a-11d and WGA, which showed high binding specificity for $N$-acetyl-D-glucosamine (NAG) and its oligomers [33,34], were therefore evaluated on the basis of fluorescence measurements. Fluorescence measurements of WGA and polymers with NAG residues were preliminarily performed in $0.65 \mu \mathrm{M}$ of WGA solution in $50 \mathrm{mM}$ Tris- $\mathrm{HCl}$ buffer $\left(\mathrm{pH}\right.$ 7.4) at $4{ }^{\circ} \mathrm{C}$ [11]. The results of the measurement using $\mathbf{1 1} \mathbf{b}$ and the analyses of the results are shown in Figure 1 as an example. The intensity of the peaks at $348 \mathrm{~nm}$ gradually increased upon addition of NAG polymer solutions, as shown in Figure 1a. The difference between the wavelengths on the maximum relative fluorescence intensity of WGA alone and WGA with the saturated concentration of a glycopolymer is represented as $\Delta \lambda$. From the results in Figure 1a, we can see that $\Delta \lambda$ was $-14.2 \mathrm{~nm}$, as shown in Table 3 . These phenomena occurred due to the change in the environment around the tryptophan residue located at or near the binding sites of WGA. The changes in fluorescence intensity were substituted into the Hill equation [35]:

$$
\log \left(\frac{\Delta F}{\Delta F_{M A X}-\Delta F}\right)=\log [S]+\log K_{a}
$$

where $\Delta F\left(\Delta F=F-F_{0}\right)$ is the difference in relative fluorescence intensity at $348 \mathrm{~nm}$ of WGA between $F$, which is the fluorescence intensity of WGA with various concentrations of a glycopolymer and $F_{0}$, which is fluorescence intensity of a solution of WGA itself (without a glycopolymer); and $\triangle F_{M A X}$ is the difference between $F_{M A X}$, which is the final fluorescence intensity at the saturated concentration of a glycopolymer, and $F_{0}$.

(a)

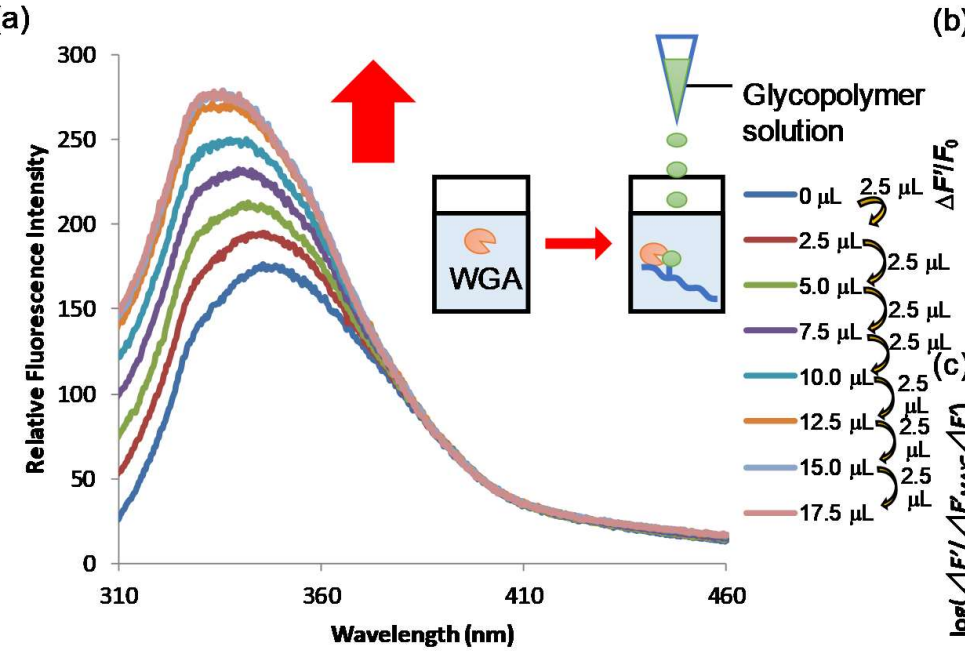

(b) 0.5

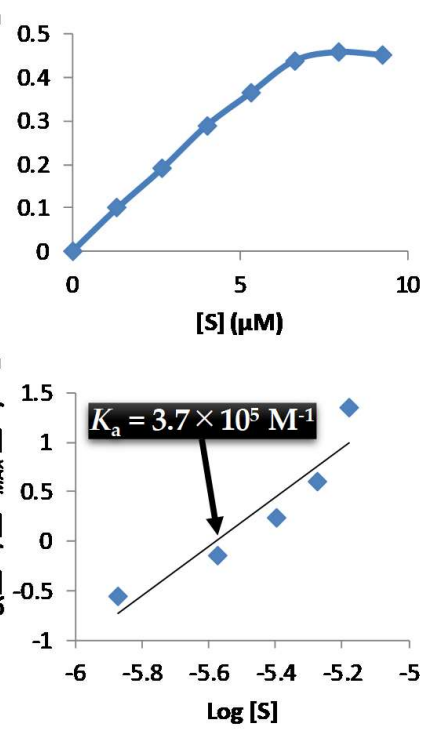

Figure 1. Biological evaluations of the WGA-carbohydrate interaction of $\mathbf{1 1} \mathbf{b}$. (a) Changes in fluorescence emission spectra of WGA $(0.65 \mu \mathrm{M}, 3.0 \mathrm{~mL}, 50 \mathrm{mM}$ Tris- $\mathrm{HCl}$ buffer containing $150 \mathrm{mM}$ $\left.\mathrm{NaCl}, \mathrm{pH} 7.4,4^{\circ} \mathrm{C}\right)$ upon addition of $2.5-\mu \mathrm{L}$ aliquots of glycopolymer $\mathbf{1 1 b}(74.5 \mu \mathrm{M})$. (b) Plots of $\Delta F^{\prime} / F_{0}$ versus [S], where $\Delta F^{\prime}$ is the change in the intensity at $348 \mathrm{~nm}$ of WGA with various concentrations of $\mathbf{1 1 b}, F_{0}$ is the intensity of WGA alone, and [S] is total ligand concentration. (c) Hill plots of log $\left[\Delta F^{\prime} /\left(\Delta F^{\prime}{ }_{M A X}-\Delta F^{\prime}\right)\right]$ versus $\log [S]$. 
Table 3. Results of the binding assays for WGA on the basis of fluorescence measurements.

\begin{tabular}{ccccc}
\hline Compounds & $\boldsymbol{\Delta} \boldsymbol{\lambda}(\mathbf{n m})$ & $\left|\boldsymbol{\Delta} \boldsymbol{F}^{\prime} / \boldsymbol{F}_{\mathbf{0}}\right| \mathbf{( \% )}$ & $\boldsymbol{K}_{\boldsymbol{a}}\left(\mathbf{M}^{-\mathbf{1}}\right)$ & Relative Potency \\
\hline GlcNAc & 0 & 5 & $8.2 \times 10^{3}$ & 1 \\
$\mathbf{1 0}$ & - & 90 & $5.0 \times 10^{4}$ & 6 \\
$\mathbf{1 1 a}$ & -14.2 & 33 & $1.8 \times 10^{5}$ & 22 \\
$\mathbf{1 1 b}$ & -14.2 & 46 & $3.7 \times 10^{5}$ & 45 \\
$\mathbf{1 1 c}$ & -13.0 & 50 & $3.5 \times 10^{5}$ & 43 \\
$\mathbf{1 1 d}$ & -16.0 & 58 & $4.2 \times 10^{5}$ & 51 \\
\hline
\end{tabular}

The influence of the dilution of the WGA concentration by the addition of a glycopolymer solution was corrected using the following equation:

$$
\Delta F^{\prime}=\frac{V}{V_{0}} \Delta F
$$

where $V_{0}$ is the initial volume of the WGA solution and $V$ is the measured volume of the WGA solution with a given glycopolymer concentration based on the sugar unit in the glycopolymer [S]; Equation (1), therefore, is represented as

$$
\log \left(\frac{\Delta F^{\prime}}{\Delta F^{\prime}{ }_{M A X}-\Delta F^{\prime}}\right)=\log [S]+\log K_{a}
$$

When $\Delta F^{\prime} / F_{0}$ was plotted versus [S], as shown in Figure $1 \mathrm{~b}$, an enhancement of the relative fluorescence intensity by about $46 \%$ was observed, as shown in Table 3. From the results of a Hill plot of $\log \left[\Delta F /\left(\Delta F_{M A X}-\Delta F\right)\right]$ versus $\log [S]$, as shown in Figure $1 c$, the association constant $K_{a}$ was estimated to be $3.7 \times 10^{5} \mathrm{M}^{-1}$. The results for other glycopolymers against WGA are summarized in Table 3. Association constants were estimated to be $1.8-4.2 \times 10^{5} \mathrm{M}^{-1}$. The association constant $K_{a}$ was the largest when copolymer 11d was used. This can be explained by the suitable density of the carbohydrate moieties on the glycopolymer, as the ligand was possibly the best fit for the location of each binding site on WGA [36]. However, their $K_{a}$ values were nearly in the same molar range. In addition to the fluorometric assays for the glycopolymers, biological evaluations of some of the glycopolymers and WGA were carried out by means of surface plasmon resonance (SPR) [37]. The results of the SPR analyses showed that the $K_{a}$ for $11 \mathbf{b}$ was $3.30 \times 10^{5} \mathrm{M}^{-1}$; for $11 \mathrm{c}$ it was $3.41 \times 10^{5} \mathrm{M}^{-1}$. These $K_{a}$ values were in good agreement with the results from the fluorometric assay measurements in this study. From the results of the biological evaluation of the glycopolymers for lectin, we can see that these types of glycopolymers also have a sugar-clustering effect [38-40].

\section{Experimental}

\subsection{Materials and Methods}

Unless otherwise stated, all commercially available solvents and reagents were used without further purification. $N, N$-Dimethylformamide (DMF) was stored over molecular sieves (4 A MS) and methanol $(\mathrm{MeOH})$ was stored over $3 \AA$ MS before use. Acrylamide was recrystallized from benzene before use. Optical rotations were determined with a JASCO DIP-1000 digital polarimeter (JASCO Corp., Tokyo, Japan). IR spectra were obtained using a Shimadzu IR Prestige-21 spectrometer (Shimadzu Corp., Kyoto, Japan). ${ }^{1} \mathrm{H}-\mathrm{NMR}$ spectra were recorded at $400 \mathrm{MHz}$ for ${ }^{1} \mathrm{H}$ and at $100 \mathrm{MHz}$ for ${ }^{13} \mathrm{C}$ with a Bruker DPX-400 spectrometer or at $500 \mathrm{MHz}$ for ${ }^{1} \mathrm{H}$ and at $125 \mathrm{MHz}$ for ${ }^{13} \mathrm{C}$ with a Bruker AVANCE 500 spectrometer (Bruker BioSpin, Ettlingen, Germany) in chloroform- $d\left(\mathrm{CDCl}_{3}\right)$ or deuterium oxide $\left(\mathrm{D}_{2} \mathrm{O}\right)$. Chemical shifts are expressed as parts per million $(\mathrm{ppm}, \delta)$ and are relative to an internal tetramethylsilane (TMS) in $\mathrm{CDCl}_{3}(\delta 0.0)$ or $\mathrm{HDO}$ in $\mathrm{D}_{2} \mathrm{O}(\delta 4.78)$ for ${ }^{1} \mathrm{H}$ and $\mathrm{CHCl}_{3}$ in $\mathrm{CDCl}_{3}$ ( $\left.\delta 77.0\right), \mathrm{CH}_{3}$ in MeOD ( $\left.\delta 49.0\right)$ or $\mathrm{CH}_{3}$ in acetone $(\delta 215.0)$ for ${ }^{13} \mathrm{C}$. Ring-proton assignments in the ${ }^{1} \mathrm{H}$-NMR spectra were made by first-order analysis of the spectra and are supported by the 
results of homonuclear decoupling experiments and $\mathrm{H}-\mathrm{H}$ or HMQC experiments. Elemental analyses were performed with a Fisons EA1108 (Thermo Fisher Scientific Inc., Waltham, MA, USA) on samples that were extensively dried at $50-60{ }^{\circ} \mathrm{C}$ over phosphorus pentoxide for $4-5 \mathrm{~h}$. Matrix-assisted laser desorption/ionization time-of-flight mass spectra (MALDI-TOF-MS) were obtained using a Bruker AutoflexIII spectrometer (Bruker Daltonics, Bremen, Germany). Reactions were monitored by thin layer chromatography (TLC) on a precoated plate of silica gel $60 \mathrm{~F}_{254}$ (layer thickness, $0.25 \mathrm{~mm}$; E. Merck, Darmstadt, Germany). For the detection of the intermediates, TLC sheets were (a) dipped in a solution of 85:10:5 $(v / v / v)$ MeOH-p-anisaldehyde-concd $\mathrm{H}_{2} \mathrm{SO}_{4}$ and heated for a few minutes (for carbohydrate); or (b) dipped in an aq solution of $5 \mathrm{wt} \% \mathrm{KMnO}_{4}$ and heated similarly (for detection of $\mathrm{C}=\mathrm{C}$ double bonds). Column chromatography was performed on silica gel (Silica Gel 60; 63-200 $\mu \mathrm{m}$, E. Merck, Darmstadt, Germany). Flush column chromatography was also performed on silica gel (Silica Gel 60, spherical neutral; 40-100 $\mu \mathrm{m}$, E. Merck, Darmstadt, Germany). All extractions were concentrated below $45{ }^{\circ} \mathrm{C}$ under diminished pressure. Dialysis was performed against distilled water using a dialysis tubing [molecular cutoff (MWCO): 12 k-16 kDa, Dow Chemical Co., Midland, MI, USA]. Wheat germ agglutinin (WGA; a lectin from Triticum vulgaris) was purchased from J-Oil Mills (Lot \# 62015) (J-Oil Mills, Inc., Tokyo, Japan).

\subsection{Synthesis}

\subsubsection{4-Azidomethylstyrene (AZ-Str) (2)}

To a solution of chloromethyl styrene $\mathbf{1}$ (CM-Str) $(10.0 \mathrm{~g}, 65.5 \mathrm{mmol})$ in DMF $(50 \mathrm{~mL})$ was added sodium azide $(12.4 \mathrm{~g}, 190 \mathrm{mmol})$ and the mixture was stirred at $80{ }^{\circ} \mathrm{C}$ for $1.0 \mathrm{~h}$. After the complete vanishing of $\mathbf{1}$ judged by TLC, the reaction mixture was evaporated in vacuo. The residue was diluted with $\mathrm{CHCl}_{3}$ and was then washed successively with water and brine and dried over anhyd $\mathrm{MgSO}_{4}$. The organic solution was filtered and evaporated in vacuo. The residual syrup was applied to a column of silica gel with 40:1 $(v / v)$ hexane-EtOAc as the eluent to give pure AZ-Str $2(9.40 \mathrm{~g}, 90.1 \%)$ as a yellow syrup: $\mathrm{R}_{\mathrm{f}} 0.28$ [hexane]; IR (NEAT) $3088(v \mathrm{C}-\mathrm{H}, \mathrm{Ph}), 2930\left(v_{\mathrm{C}-\mathrm{H}}\right), 2097\left(v_{\mathrm{N}=\mathrm{N}=\mathrm{N}}\right), 1630\left(v_{\mathrm{C}=\mathrm{C}}\right)$ $\mathrm{cm}^{-1}$; ${ }^{1} \mathrm{H}-\mathrm{NMR}\left(500 \mathrm{MHz}, \mathrm{CDCl}_{3}\right): \delta 7.43(\mathrm{~d}, 2 \mathrm{H}, J=8.15 \mathrm{~Hz}, \mathrm{Ph}), 7.28(\mathrm{~d}, 2 \mathrm{H}, J=8.15 \mathrm{~Hz}, \mathrm{Ph}), 6.72$ $\left(\mathrm{dd}, 1 \mathrm{H}, J_{\text {cis }}=10.85 \mathrm{~Hz}, J_{\text {trans }}=17.60 \mathrm{~Hz}, \mathrm{CH}=\right), 5.77\left[\mathrm{dd}, 1 \mathrm{H}, J_{\text {gem }}=0.50 \mathrm{~Hz}\right.$, trans of $\left.\mathrm{CH}_{2}=\right], 5.28[\mathrm{dd}$, $1 \mathrm{H}$, cis of $\left.\mathrm{CH}_{2}=\right], 4.32\left(\mathrm{~s}, 2 \mathrm{H}, \mathrm{PhCH}_{2}\right)$.

\subsubsection{Aminomethylstyrene (AMN-Str) (3)}

To a solution of AZ-Str $2(3.00 \mathrm{~g}, 18.8 \mathrm{mmol})$ in anhydr THF $(10 \mathrm{~mL})$ was added triphenyl phosphine (TPP) $(4.94 \mathrm{~g}, 20.7 \mathrm{mmol}) . \mathrm{H}_{2} \mathrm{O}(30 \mathrm{~mL})$ was added to the solution at $0{ }^{\circ} \mathrm{C}$ and the mixture was stirred at room temperature for $2.5 \mathrm{~h}$. After the complete transformation of the AZ-Str 2 judged by TLC, the reaction mixture was diluted with $\mathrm{CHCl}_{3}$ and the mixture was shaken with $3 \mathrm{M}$ aq $\mathrm{H}_{2} \mathrm{SO}_{4}$. The extraction was partitioned and the aqueous layer was treated with $\mathrm{NaOH}$ until ca. $\mathrm{pH} 12$ to produce precipitates. To the mixture was added $\mathrm{CHCl}_{3}$ and the organic solution was washed with brine, dried over anhyd $\mathrm{MgSO}_{4}$, and evaporated to give pure AMN-Str 3 [24] (2.40 g, 95.6\%) as a yellow syrup: $R_{\mathrm{f}} 0.37$ [5:5:1 $(v / v / v) \mathrm{CHCl}_{3}-\mathrm{MeOH}-$ water]; IR (NEAT) $3281\left(v_{\mathrm{N}-\mathrm{H}}\right), 3005\left(v_{\mathrm{C}-\mathrm{H}}, \mathrm{Ph}\right)$, $1628\left(\delta_{\mathrm{N}-\mathrm{H}}\right) \mathrm{cm}^{-1} ;{ }^{1} \mathrm{H}-\mathrm{NMR}\left(500 \mathrm{MHz}, \mathrm{CDCl}_{3}\right): \delta 7.39(\mathrm{~d}, 2 \mathrm{H}, J=8.10 \mathrm{~Hz}, \mathrm{Ph}), 7.27(\mathrm{~d}, 2 \mathrm{H}, J=9.15 \mathrm{~Hz}$, $\mathrm{Ph}), 6.71\left(\mathrm{dd}, 1 \mathrm{H}, J_{\text {cis }}=10.90 \mathrm{~Hz}, J_{\text {trans }}=17.60 \mathrm{~Hz}, \mathrm{CH}=\right), 5.73\left(\mathrm{dd}, 1 \mathrm{H}, J_{\text {gem }}=0.83 \mathrm{~Hz}\right.$, trans of $\left.\mathrm{CH}_{2}=\right)$ $5.28\left(\mathrm{dd}, 1 \mathrm{H}\right.$, cis of $\left.\mathrm{CH}_{2}=\right), 3.86\left(\mathrm{~s}, 2 \mathrm{H}, \mathrm{PhCH}_{2}\right), 1.56\left(\mathrm{~s}, 2 \mathrm{H}, \mathrm{NH}_{2}\right)$.

\subsubsection{4-\{[5-(Dimethylamino)-1-naphthalenesulfonamido]methyl\}styrene (DSL-Str) (4)}

To a stirred solution of AMN-Str $3(512 \mathrm{mg}, 3.8 \mathrm{mmol})$ and $\mathrm{Et}_{3} \mathrm{~N}(0.53 \mathrm{~mL}, 456 \mathrm{mmol})$ in dichloromethane $(50 \mathrm{~mL})$ a solution of dansyl chloride $(1.23 \mathrm{~g}, 4.56 \mathrm{mmol})$ in dichloromethane $(40 \mathrm{~mL})$ was added dropwise at room temperature under a $\mathrm{N}_{2}$ atmosphere. After stirring at room temperature for $5.5 \mathrm{~h}$, the reaction mixture was evaporated in vacuo. The resulting mixture was diluted with $\mathrm{CHCl}_{3}$ and was then washed successively with water and brine and dried over anhyd $\mathrm{MgSO}_{4}$. The organic 
mixture was filtered and evaporated in vacuo. The residual syrup was applied to a column of silica gel with 5:2 $(v / v)$ hexane-EtOAc as the eluent to give pure DSL-Str 4 [26] (1.052 g, 75.5\%) as yellow crystals: $\mathrm{mp}$ 103.0-103.4 ${ }^{\circ} \mathrm{C} ; R_{\mathrm{f}} 0.40$ [5:2 $(v / v)$ hexane-EtOAc]; IR (NEAT): 3286.70, $3273.20\left(v_{\mathrm{N}-\mathrm{H}}\right)$, $3084.18\left(v_{\mathrm{C}-\mathrm{H}}, \mathrm{Ph}\right), 1625.99\left(\delta_{\mathrm{N}-\mathrm{H}}\right), 1305.81\left(v_{\mathrm{C}-\mathrm{N}}\right), 1066.64\left(v_{\mathrm{S}=\mathrm{O}}\right) \mathrm{cm}^{-1} ;{ }^{1} \mathrm{H}-\mathrm{NMR}\left(500 \mathrm{MHz}, \mathrm{CDCl}_{3}\right): \delta$ $8.53(\mathrm{~d}, 2 \mathrm{H}, J=8.50 \mathrm{~Hz}, \mathrm{Naph}), 8.27(\mathrm{t}, 2 \mathrm{H}, J=8.85 \mathrm{~Hz}, J=7.45 \mathrm{~Hz}, \mathrm{Naph}), 7.53(\mathrm{dt}, 2 \mathrm{H}, J=10.90 \mathrm{~Hz}$, $J=17.60 \mathrm{~Hz}, \mathrm{Naph}), 7.19$ (d, $2 \mathrm{H}, J=7.95 \mathrm{~Hz}, \mathrm{Ph}) 7.19$ (d, $1 \mathrm{H}, J=6.35 \mathrm{~Hz}, \mathrm{Naph}), 7.01$ (d, $2 \mathrm{H}$, $J=7.80 \mathrm{~Hz}, \mathrm{Ph}), 6.60(\mathrm{dd}, 1 \mathrm{H}, J=10.87 \mathrm{~Hz}, J=17.53 \mathrm{~Hz}, \mathrm{Naph}), 5.66(\mathrm{br} \mathrm{dd}, 1 \mathrm{H}, J=17.61 \mathrm{~Hz}, \mathrm{Naph})$, $5.20(\mathrm{br} \mathrm{dd}, 1 \mathrm{H}, J=10.85 \mathrm{~Hz}, \mathrm{Naph}), 4.86(\mathrm{t}, 2 \mathrm{H}, J=\sim 6 \mathrm{~Hz}, \mathrm{NH}), 4.06\left(\mathrm{~d}, 2 \mathrm{H}, J=6.05 \mathrm{~Hz}, \mathrm{CH}_{2}\right), 2.89$ (s, $\left.6 \mathrm{H}, \mathrm{NCH}_{3} \times 2\right)\left({ }^{1} \mathrm{H}-\mathrm{MNR}\right.$ spectrum can be found in Supplementary Materials).

3.2.4. 4-(\{5-[(3aR,6S,6aS)-2-Oxo-1,3,3a,4,6,6a-hexahydrothieno[3,4-d]imidazol-6yl]pentanamido\}methyl)-styrene (BTN-Str) (5)

To a stirred solution of AMN-Str $3(60.0 \mathrm{mg}, 0.45 \mathrm{mmol})$ and biotin $(121 \mathrm{mg}, 495 \mathrm{mmol})$ in DMF $(1 \mathrm{~mL})$ was added DMT-MM $(150 \mathrm{mg}, 0.54 \mathrm{mmol})$ at room temperature under a $\mathrm{N}_{2}$ atmosphere. After stirring at room temperature for $1.5 \mathrm{~h}$, the white suspension was poured into ice-cold water and extracted with EtOAc. When extraction with EtOAc was performed, an insoluble mass was also observed. The organic solution and the insoluble mass were successively washed with ice-cold water, satd aq $\mathrm{NaHCO}_{3}$ and brine, and the whole mixture was filtrated to give a white amorphous powder BTN-Str 5 (148 mg, 91.3\%): $R_{\mathrm{f}}=0.53\left[5: 1(v / v) \mathrm{CHCl}_{3}-\mathrm{MeOH}\right] ;{ }^{1} \mathrm{H}-\mathrm{NMR}\left(500 \mathrm{MHz}\right.$, DMSO- $\left.d_{6}\right): \delta$ $8.34\left(\mathrm{br} \mathrm{s}, 1 \mathrm{H}, \mathrm{NHCH}_{2}\right), 7.41(\mathrm{~d}, 2 \mathrm{H}, J=8.15 \mathrm{~Hz}, \mathrm{Ph}), 7.21(\mathrm{~d}, 2 \mathrm{H}, J=8.15 \mathrm{~Hz}, \mathrm{Ph}), 6.71(\mathrm{dd}, 1 \mathrm{H}$, $\left.J_{\text {cis }}=10.95 \mathrm{~Hz}, J_{\text {trans }}=17.65 \mathrm{~Hz}, \mathrm{CH}=\mathrm{CH}_{2}\right), 6.42[\mathrm{br} \mathrm{s}, 1 \mathrm{H}, \mathrm{NH}$ (biotin)], 6.37 [s, $1 \mathrm{H}, \mathrm{NH}$ (biotin)], 5.79 $\left(\mathrm{dd}, 1 \mathrm{H}, J_{\text {gem }}=0.70 \mathrm{~Hz}\right.$, trans of $\left.\mathrm{CH} 2=\right), 5.22\left(\mathrm{~d}, 1 \mathrm{H}\right.$, cis of $\left.\mathrm{CH}_{2}=\right), 4.30[\mathrm{dd}, 1 \mathrm{H}, J=5.15 \mathrm{~Hz}, J=7.65 \mathrm{~Hz}$, $\mathrm{CHCH}_{2}$ (biotin)], 4.24 (d, $2 \mathrm{H}, J=5.95 \mathrm{~Hz}, \mathrm{PhCH}_{2}$ ), 4.12 (ddd, $1 \mathrm{H}, J=1.80 \mathrm{~Hz}, J=4.35 \mathrm{~Hz}, J=7.45 \mathrm{~Hz}$, $\mathrm{NHCHCH}), 3.09(\mathrm{ddd}, 1 \mathrm{H}, J=2.55 \mathrm{~Hz}, J=4.35 \mathrm{~Hz}, J=10.5 \mathrm{~Hz}, \mathrm{SCH}), 2.82\left(\mathrm{dd}, 1 \mathrm{H}, J_{\text {gem }}=12.4 \mathrm{~Hz}\right.$, $\left.\mathrm{SCH}_{\mathrm{a}}\right), 2.58\left(\mathrm{~d}, 1 \mathrm{H}, \mathrm{SCH}_{\mathrm{b}}\right), 2.14\left(\mathrm{t}, 2 \mathrm{H}, J=7.45 \mathrm{~Hz}, \mathrm{CH}_{2} \mathrm{CO}\right), 1.5\left(\mathrm{~m}, 4 \mathrm{H}, \mathrm{CH}_{2} \times 2\right)\left({ }^{1} \mathrm{H}-\mathrm{MNR}\right.$ spectrum can be found in Supplementary Materials).

3.2.5. 2-[2-(2-Hydroxyethoxy)-ethoxy]-ethyl-O-2-acetamido-3,4,6-tri-O-acetyl-2-deoxy$\beta$-D-glucopyranoside (7)

The quantitative preparation of an oxazoline 6 was accomplished from 2-acetamido-1,3,4,6-tetra$O$-acetyl- $\alpha$-D-glucosamine $(2.00 \mathrm{~g}, 5.14 \mathrm{mmol})$ by the method previously reported [29]. To a solution of oxazoline and 2,2'-[ethane-1,2-diylbis(oxy)]di(ethan-1-ol) $(3.4 \mathrm{~mL}, 25.6 \mathrm{mmol})$ in dichloroethane $(17 \mathrm{~mL})$ was added CSA $(0.12 \mathrm{~g}, 0.51 \mathrm{mmol})$ under a $\mathrm{N}_{2}$ atmosphere and the reaction mixture was stirred at $90{ }^{\circ} \mathrm{C}$ for $1 \mathrm{~h}$. After cooling the reaction mixture, $\mathrm{CHCl}_{3}$ was added. The organic mixture was successively washed with water, satd aq $\mathrm{NaHCO}_{3}$ and brine, dried over anhyd $\mathrm{MgSO}_{4}$, filtered, and evaporated to yield a dark yellow syrup, which was applied to a column of silica gel with 20:1 $(v / v) \mathrm{CHCl}_{3}-\mathrm{MeOH}$ as the eluent to afford pure $7(1.87 \mathrm{~g}, 75.7 \%)$ as a yellow syrup: $R_{\mathrm{f}}=0.39[10: 1$ $(v / v) \mathrm{CHCl}_{3}-\mathrm{MeOH}$ ]; IR (NEAT): $3294\left(v_{\mathrm{O}-\mathrm{H}}\right), 2924\left(v_{\mathrm{C}-\mathrm{H}}\right), 1748\left(v_{\mathrm{C}=\mathrm{O}}\right.$, ester $), 1660\left(v_{\mathrm{C}=\mathrm{O}}\right.$, amide I$)$, $1557\left(\delta_{\mathrm{N}-\mathrm{H}}\right.$, amide II $), 1236\left(v_{\mathrm{C}-\mathrm{O}}\right), 1043\left(v_{\mathrm{C}-\mathrm{O}-\mathrm{C}}\right) \mathrm{cm}^{-1} ;{ }^{1} \mathrm{H}-\mathrm{NMR}\left(500 \mathrm{MHz}, \mathrm{CDCl}_{3}\right): \delta 6.80(\mathrm{~d}, 1 \mathrm{H}$, $\left.J_{2, \mathrm{NH}}=9.30 \mathrm{~Hz}, \mathrm{NH}\right), 5.11\left(\mathrm{dd}, 1 \mathrm{H}, J_{2,3}=10.0 \mathrm{~Hz}, J_{3,4}=9.30 \mathrm{~Hz}, \mathrm{H}-3\right), 5.07\left(\mathrm{t}, 1 \mathrm{H}, J_{4,5}=9.60 \mathrm{~Hz}, \mathrm{H}-4\right)$, $4.77\left(\mathrm{~d}, 1 \mathrm{H}, J_{1,2}=8.60 \mathrm{~Hz}, \mathrm{H}-1\right), 4.26\left(\mathrm{dd}, 1 \mathrm{H}, J_{5,6 \mathrm{~b}}=4.65 \mathrm{~Hz}, J_{6 \mathrm{a}, 6 \mathrm{~b}}=12.3 \mathrm{~Hz}, \mathrm{H}-6 \mathrm{~b}\right), 4.12(\mathrm{q}, 1 \mathrm{H}$, $\mathrm{H}-2), 4.12\left(\mathrm{dd}, 1 \mathrm{H}, J_{5,6 \mathrm{a}}=2.60 \mathrm{~Hz}, \mathrm{H}-6 \mathrm{a}\right), 3.90\left(\mathrm{dt}, 1 \mathrm{H}, J=12.65 \mathrm{~Hz}, J=2.48 \mathrm{~Hz}, \mathrm{OCH}_{\mathrm{a}}\right), 3.86-3.60(\mathrm{~m}$, $\left.12 \mathrm{H}, \mathrm{H}-5, \mathrm{OCH}_{2} \times 5, \mathrm{OCH}_{\mathrm{b}}\right), 3.08(\mathrm{br} \mathrm{s}, 1 \mathrm{H}, \mathrm{OH}), 2.09,2.02,2.01$, and 1.98 (each s, $12 \mathrm{H}, \mathrm{COCH}_{3} \times 4$ ) $\left({ }^{1} \mathrm{H}-\mathrm{MNR}\right.$ spectrum can be found in Supplementary Materials); ${ }^{13} \mathrm{C}-\mathrm{NMR}\left(100 \mathrm{MHz}, \mathrm{CDCl}_{3}\right): \delta 171.77$, 170.94, 170.94, and $169.48(\mathrm{C}=\mathrm{O} \times 4), 102.05(\mathrm{C}-1), 73.88(\mathrm{C}-3), 72.50\left(\mathrm{OCH}_{2}\right), 71.71(\mathrm{C}-5), 71.67\left(\mathrm{OCH}_{2}\right)$, $70.69\left(\mathrm{OCH}_{2}\right), 70.25\left(\mathrm{OCH}_{2}\right), 68.78(\mathrm{C}-4), 68.69\left(\mathrm{OCH}_{2}\right), 62.30(\mathrm{C}-6), 61.39\left(\mathrm{OCH}_{2}\right), 54.01(\mathrm{C}-2), 23.12$ $\left(\mathrm{NCOCH}_{3}\right), 20.94,20.89$ and $20.75\left(\mathrm{COCH}_{3} \times 3\right)$. 
3.2.6. 8-O-(2-Acetamido-3,4,6-tri-O-acetyl-2-deoxy- $\beta$-D-glucopyranosyl)-3,6-dioxaoctanoic Acid (8)

An aqueous $15 \%$ solution of $\mathrm{NaHCO}_{3}(19 \mathrm{~mL})$ was added to a solution of alcohol 7 (5.58 g, $11.6 \mathrm{mmol})$ in acetone $(18 \mathrm{~mL})$ with stirring at $0{ }^{\circ} \mathrm{C} . \mathrm{KBr}(0.28 \mathrm{~g}, 2.3 \mathrm{mmol})$ and TEMPO $(36.4 \mathrm{mg}$, $0.23 \mathrm{mmol}$ ) were added to the mixture. Trichloroisocyanuric acid (5.42 $\mathrm{g}, 23.2 \mathrm{mmol})$ was then added slowly over a period of $20 \mathrm{~min}$ at $0{ }^{\circ} \mathrm{C}$. The mixture was warmed to room temperature and stirred for $4.5 \mathrm{~h}$, and then propan-2-ol was added. The mixture was filtered on celite and treated with $15 \mathrm{~mL}$ of satd aq $\mathrm{NaHCO}_{3}$. The aqueous phase was washed with portions of $\mathrm{CHCl}_{3}$, treated with $1 \mathrm{M}$ aq $\mathrm{HCl}$ and brine, and extracted twice with $\mathrm{CHCl}_{3}$. The organic layers were combined and dried over anhyd $\mathrm{MgSO}_{4}$, and the solvent was evaporated after filtration on celite to yield the corresponding carboxylic acid 8, which was used for the next step without further purification: $R_{\mathrm{f}}=0.40[5: 1(v / v)$ $\mathrm{CHCl}_{3}-\mathrm{MeOH}$; IR (NEAT) $3323\left(v_{\mathrm{O}-\mathrm{H}}\right), 2931\left(v_{\mathrm{C}-\mathrm{H}}\right), 1745\left(v_{\mathrm{C}=\mathrm{O}}\right.$, ester $), 1732$ ( $v_{\mathrm{C}=\mathrm{O}}$, carboxy group), $1643\left(v_{\mathrm{C}=\mathrm{O}}\right.$, Amide I), $1556\left(\delta_{\mathrm{N}-\mathrm{H}}\right.$, Amide II $), 1373\left(\delta_{\mathrm{O}-\mathrm{H}}\right), 1234\left(v_{\mathrm{O}-\mathrm{H}}\right.$, carboxy group $), 1041\left(v_{\mathrm{C}-\mathrm{O}-\mathrm{C}}\right)$ $\mathrm{cm}^{-1},{ }^{1} \mathrm{H}-\mathrm{NMR}\left(400 \mathrm{MHz}, \mathrm{CDCl}_{3}\right): \delta 6.59\left(\mathrm{~d}, 1 \mathrm{H}, J_{2, \mathrm{NH}}=9.20 \mathrm{~Hz}, \mathrm{NH}\right), 5.15\left(\mathrm{t}, 1 \mathrm{H}, J_{2,3}=10.2 \mathrm{~Hz}\right.$, $\left.J_{3,4}=9.48 \mathrm{~Hz}, \mathrm{H}-3\right), 5.07\left(\mathrm{t}, 1 \mathrm{H}, J_{4,5}=9.65 \mathrm{~Hz}, \mathrm{H}-4\right), 4.87\left(\mathrm{~d}, 1 \mathrm{H}, J_{1,2}=8.52 \mathrm{~Hz}, \mathrm{H}-1\right), 4.27(\mathrm{dd}, 1 \mathrm{H}$, $\left.J_{5,6 \mathrm{~b}}=4.60 \mathrm{~Hz}, J_{6 \mathrm{a}, 6 \mathrm{~b}}=12.2 \mathrm{~Hz}, \mathrm{H}-6 \mathrm{~b}\right), 4.14\left(\mathrm{dd}, 1 \mathrm{H}, J_{5,6 \mathrm{a}}=2.24 \mathrm{~Hz}, \mathrm{H}-6 \mathrm{a}\right) 4.06(\mathrm{q}, 1 \mathrm{H}, \mathrm{H}-2), 3.94-3.61$ $\left(\mathrm{m}, 11 \mathrm{H}, \mathrm{H}-5 \& \mathrm{OCH}_{2} \times 5\right), 2.09,2.02,2.01$, and $1.97\left(\right.$ each s, $\left.12 \mathrm{H}, \mathrm{COCH}_{3} \times 4\right)\left({ }^{1} \mathrm{H} \mathrm{MNR}\right.$ spectra can be found in Supplementary Materials); ${ }^{13} \mathrm{C}-\mathrm{NMR}\left(100 \mathrm{MHz}, \mathrm{CDCl}_{3}\right): \delta 172.01,171.47,171.47,171.19$, and $169.56(\mathrm{C}=\mathrm{O} \times 5), 101.87(\mathrm{C}-1), 73.34(\mathrm{C}-3), 71.77(\mathrm{C}-5), 71.38\left(\mathrm{OCH}_{2}\right), 70.40\left(\mathrm{OCH}_{2}\right), 68.81\left(\mathrm{OCH}_{2}\right)$, $68.55(\mathrm{C}-4), 68.25\left(\mathrm{OCH}_{2}\right), 62.38(\mathrm{C}-6), 54.20(\mathrm{C}-2), 25.44\left(\mathrm{OCH}_{2}\right), 23.10\left(\mathrm{NCOCH}_{3}\right), 20.94,20.90$ and $20.78\left(\mathrm{COCH}_{3} \times 3\right)$; MALDI-TOF MS calcd for $[\mathrm{M}+\mathrm{Na}]^{+}: 515.169$. Found: $m / z 516.101,[\mathrm{M}+\mathrm{K}]^{+}$: 532.143. Found: $m / z 532.083$.

3.2.7. 8-O-(2-Acetamido-3,4,6-tri-O-acetyl-2-deoxy- $\beta$-D-glucopyranosyl)-3,6-dioxaoctanoic Acid 4-vinybenzylamide (9)

To a stirred solution of carboxylic acid $8(4.0 \mathrm{~g}, 8.11 \mathrm{mmol})$ and AMN-Str $3(1.24 \mathrm{~g}, 9.31 \mathrm{mmol})$ in dichloromethane $(20 \mathrm{~mL})$ was added DMT-MM $(2.69 \mathrm{~g}, 9.72 \mathrm{mmol})$ and the resulting suspension was stirred at room temperature under a $\mathrm{N}_{2}$ atmosphere for $3.5 \mathrm{~h}$. The reaction mixture was poured into ice-cold water and extracted with EtOAc. The organic layer was successively washed with satd aq $\mathrm{NaHCO}_{3}$ and brine. The organic layer was dried over anhyd MgSO4 and concentrated in vacuo. The residue was purified by silica gel chromatography with $50: 1(v / v) \mathrm{CHCl}_{3}-\mathrm{MeOH}$ as the eluent to give styrene derivative $9(3.82 \mathrm{~g}, 77.7 \%)$ as a colorless syrup: $R_{\mathrm{f}}=0.48\left[10: 1(v / v) \mathrm{CHCl}_{3}-\mathrm{MeOH}\right]$; IR (NEAT) $3306\left(v_{\mathrm{N}-\mathrm{H}}\right)$, 3086, $3007\left(v_{\mathrm{C}-\mathrm{H}}, \mathrm{Ph}\right), 2937\left(v_{\mathrm{C}-\mathrm{H}}\right), 1748\left(v_{\mathrm{C}=\mathrm{O}}\right.$, ester $), 1667\left(v_{\mathrm{C}=\mathrm{O}}\right.$, Amide I), 1651 ( $\left.v_{\mathrm{C}=\mathrm{C}}\right), 1537\left(\delta_{\mathrm{N}-\mathrm{H}}\right.$, Amide II), $1234(v \mathrm{C}-\mathrm{O}), 1043\left(v_{\mathrm{C}-\mathrm{O}-\mathrm{C}}\right) \mathrm{cm}^{-1} ;{ }^{1} \mathrm{H}-\mathrm{NMR}\left(400 \mathrm{MHz}, \mathrm{CDCl}_{3}\right)$ : $\delta 7.39\left(\mathrm{~d}, 2 \mathrm{H}, J_{\text {vic }}=8.1 \mathrm{~Hz}, \mathrm{Ph}\right), 7.27\left(\mathrm{~d}, 2 \mathrm{H}, J_{\text {vic }}=8.3 \mathrm{~Hz}, \mathrm{Ph}\right), 7.23(\mathrm{~s}, 1 \mathrm{H}, \mathrm{NHCH}), 6.71(\mathrm{dd}, 1 \mathrm{H}$, $\left.J_{\text {cis }}=10.9 \mathrm{~Hz}, J_{\text {trans }}=17.6 \mathrm{~Hz}, \mathrm{CH}=\mathrm{CH}_{2}\right), 6.30\left(\mathrm{~d}, 1 \mathrm{H}, J_{2, \mathrm{NH}}=8.52 \mathrm{~Hz}, \mathrm{NHAc}\right), 5.75\left(\mathrm{dd}, 1 \mathrm{H}, J_{\text {gem }}=\right.$ $0.60 \mathrm{~Hz}$, trans of $\left.\mathrm{CH}_{2}=\right), 5.35\left(\mathrm{dd}, 1 \mathrm{H}, \mathrm{J}_{2,3}=10.5 \mathrm{~Hz}, \mathrm{~J}_{3,4}=9.34 \mathrm{~Hz}, \mathrm{H}-3\right), 5.26\left(\mathrm{dd}, 1 \mathrm{H}\right.$, cis of $\left.\mathrm{CH}_{2}=\right)$, $5.03\left(\mathrm{t}, 1 \mathrm{H}, J_{4,5}=9.72 \mathrm{~Hz}, \mathrm{H}-4\right), 4.79\left(\mathrm{~d}, 1 \mathrm{H}, J_{1,2}=8.36 \mathrm{~Hz}, \mathrm{H}-1\right), 4.49\left(\mathrm{~d}, 2 \mathrm{H}, J_{\text {vic }}=5.92 \mathrm{~Hz}, \mathrm{NHCH}_{2}\right)$, $4.24\left(\mathrm{dd}, 1 \mathrm{H}, J_{5,6 \mathrm{~b}}=4.66 \mathrm{~Hz}, J_{6 \mathrm{a}, 6 \mathrm{~b}}=12.3 \mathrm{~Hz}, \mathrm{H}-6 \mathrm{~b}\right), 4.19\left(\mathrm{~d}, 1 \mathrm{H}, J_{\mathrm{gem}}=15.7 \mathrm{~Hz}, \mathrm{NCOCH}_{\mathrm{b}}\right), 4.13(\mathrm{~d}, 1$ $\left.\mathrm{H}, \mathrm{NCOCH}_{\mathrm{a}}\right), 4.10\left(\mathrm{dd}, 1 \mathrm{H}, J_{5,6 \mathrm{a}}=2.36 \mathrm{~Hz}, \mathrm{H}-6 \mathrm{a}\right), 3.88\left(\mathrm{~m}, 1 \mathrm{H}, \mathrm{OCH}_{\mathrm{b}}\right), 3.71-3.60$ (m, 9 H, H-2, H-5, $\left.\mathrm{OCH}_{\mathrm{b}}, \mathrm{OCH}_{2} \times 3\right), 2.07,2.01,2.01,1.89$ (each s, $\left.12 \mathrm{H}, \mathrm{COCH}_{3} \times 4\right)\left({ }^{1} \mathrm{H}-\mathrm{MNR}\right.$ spectrum can be found in Supplementary Materials); ${ }^{13} \mathrm{C}-\mathrm{NMR}\left(100 \mathrm{MHz}, \mathrm{CDCl}_{3}\right): \delta 170.86,170.65,170.42$, and $169.59(\mathrm{C}=\mathrm{O} \times$ 4), $136.43(\mathrm{CH}=), 128.17(\mathrm{Ph}), 126.66(\mathrm{Ph}), 114.27\left(\mathrm{CH}_{2}=\right), 100.60(\mathrm{C}-1), 72.30(\mathrm{C}-3), 71.87,71.03,70.89$, 70.70 and $70.52\left(\mathrm{C}-5, \mathrm{OCH}_{2} \times 4\right), 68.86(\mathrm{C}-4), 68.62\left(\mathrm{OCH}_{\mathrm{a}, \mathrm{b}}\right), 62.26(\mathrm{C}-6), 55.15(\mathrm{C}-2), 42.75\left(\mathrm{NCH}_{2}\right)$, $23.29\left(\mathrm{NCOCH}_{3}\right), 20.89,20.84$, and $20.77\left(\mathrm{COCH}_{3} \times 3\right)$; MALDI-TOF MS calcd for $[\mathrm{M}+\mathrm{H}]^{+}: 609.265$. Found: $m / z$ 609.228, $[\mathrm{M}+\mathrm{Na}]^{+}:$631.247. Found: $m / z$ 631.242, $[\mathrm{M}+\mathrm{K}]^{+}:$647.221. Found: $m / z 647.225$.

3.2.8. 8-O-(2-Acetamido-2-deoxy- $\beta$-D-glucopyranosyl)-3,6-dioxaoctanoic acid 4-vinybenzylamide (NAG-Str) (10)

Sodium methoxide $(53.2 \mathrm{mg}, 0.98 \mathrm{mmol})$ was added to a solution of acetate $9(2.0 \mathrm{~g}, 3.29 \mathrm{mmol})$ in $\mathrm{MeOH}(20 \mathrm{~mL})$ at room temperature under a $\mathrm{N}_{2}$ atmosphere and the reaction mixture was stirred 
for $1.5 \mathrm{~h}$. When complete disappearance of the acetate 9 on TLC was observed, IR-120B $\left(\mathrm{H}^{+}\right)$was added to the mixture. The suspension was filtered off and the filtrate was evaporated in vacuo to yield the corresponding NAG-Str $10(1.48 \mathrm{~g}, 98.9 \%)$ as a colorless syrup: $R_{\mathrm{f}}=0.41$ [65:25:4 $(\mathrm{v} / \mathrm{v} / \mathrm{v})$ $\mathrm{CHCl}_{3}-\mathrm{MeOH}-\mathrm{H}_{2} \mathrm{O}$; I IR (NEAT) $3312\left(v_{\mathrm{O}-\mathrm{H}}\right)$, 3086, $2999\left(v_{\mathrm{C}-\mathrm{H}}, \mathrm{Ph}\right), 2922\left(v_{\mathrm{C}-\mathrm{H}}\right), 1651\left(v_{\mathrm{C}=\mathrm{O}}\right.$, Amide I), $1556\left(\delta_{\mathrm{N}-\mathrm{H}}\right.$, Amide II), $1298\left(v_{\mathrm{C}-\mathrm{O}}\right), 1072\left(v_{\mathrm{C}-\mathrm{O}-\mathrm{C}}\right) \mathrm{cm}^{-1} ;{ }^{1} \mathrm{H}-\mathrm{NMR}\left(400 \mathrm{MHz}, \mathrm{D}_{2} \mathrm{O}\right): \delta 7.49(\mathrm{~d}, 2$ $\left.\mathrm{H}, J_{\text {vic }}=8.12 \mathrm{~Hz}, \mathrm{Ph}\right), 7.32\left(\mathrm{~d}, 2 \mathrm{H}, J_{\text {vic }}=8.08 \mathrm{~Hz}, \mathrm{Ph}\right), 6.78\left(\mathrm{dd}, 1 \mathrm{H}, J_{\text {cis }}=11.0 \mathrm{~Hz}, J_{\text {trans }}=17.7 \mathrm{~Hz}\right.$, $\left.\mathrm{CH}=\mathrm{CH}_{2}\right), 5.85\left(\mathrm{~d}, 1 \mathrm{H}\right.$, trans of $\left.\mathrm{CH}_{2}=\right), 5.31\left(\mathrm{~d}, 1 \mathrm{H}\right.$, cis of $\left.\mathrm{CH}_{2}=\right), 4.50\left(\mathrm{~d}, 1 \mathrm{H}, J_{1,2}=8.44 \mathrm{~Hz}, \mathrm{H}-1\right)$, $4.45\left(\mathrm{~s}, 2 \mathrm{H}, \mathrm{NHCH}_{2}\right), 4.13\left(\mathrm{~s}, 2 \mathrm{H}, \mathrm{COCH}_{2}\right), 3.92\left(\mathrm{dd}, 1 \mathrm{H}, J_{5,6 \mathrm{~b}}=4.40 \mathrm{~Hz}, J_{6 \mathrm{a}, 6 \mathrm{~b}}=12.6 \mathrm{~Hz}, \mathrm{H}-6 \mathrm{~b}\right), 3.92$ $\left(\mathrm{m}, 1 \mathrm{H}, \mathrm{OCH}_{\mathrm{b}}\right), 3.67\left(\mathrm{~m}, 9 \mathrm{H}, \mathrm{H}-2, \mathrm{H}-6 \mathrm{a}, \mathrm{OCH}_{\mathrm{a}}, \mathrm{OCH}_{2} \times 3\right), 3.55(\mathrm{~m}, 2 \mathrm{H}, \mathrm{H}-3$ and $\mathrm{H}-4), 2.02(\mathrm{~s}, 3 \mathrm{H}$, $\left.\mathrm{COCH}_{3}\right)\left({ }^{1} \mathrm{H}-\mathrm{MNR}\right.$ spectrum can be found in Supplementary Materials); ${ }^{13} \mathrm{C}-\mathrm{NMR}\left(100 \mathrm{MHz}, \mathrm{D}_{2} \mathrm{O}\right): \delta$ $174.42(\mathrm{C}=\mathrm{O}, \mathrm{NAc}), 172.47\left(\mathrm{C}=\mathrm{O}, \mathrm{NCOCH}_{2}\right), 137.43(\mathrm{Ph}), 136.68(\mathrm{Ph}), 136.24(\mathrm{CH}=), 127.76(\mathrm{Ph}), 126.48$ $(\mathrm{Ph}), 114.34\left(\mathrm{CH}_{2}=\right), 101.00(\mathrm{C}-1), 75.86(\mathrm{C}-3), 73.87(\mathrm{C}-5), 70.53\left(\mathrm{OCH}_{2}\right), 69.91(\mathrm{C}-4), 69.61\left(\mathrm{OCH}_{2} \times 2\right)$, $69.54\left(\mathrm{OCOCH}_{2}\right), 68.85\left(\mathrm{OCH}_{2}\right), 60.75(\mathrm{C}-6), 55.49(\mathrm{C}-2), 42.28\left(\mathrm{NCH}_{2}\right), 22.16\left(\mathrm{NCOCH}_{3}\right)$.

\subsection{Radical Polymerization}

A solution of NAG-Str monomer $\mathbf{1 0}$ and an appropriate amount of acrylamide (AAm) in deionized water was deaerated under reduced pressure for a few minutes, and then tetramethylethylenediamine (TEMED) (0.2 equivalent molar for 10) and ammonium persulfate (APS) ( 0.1 equivalent molar for 10) were added. The mixture was stirred at room temperature and diluted with $1 \mathrm{M}$ aq pyridine-acetic acid buffer ( $\mathrm{pH}$ 5.6). The viscous solution was dialyzed against distilled water, followed by lyophilization to provide the corresponding white powdery glycopolymers 11a-11d. The results of the radical polymerization are summarized in Table 1.

\subsection{Biological Evaluations of Glycopolymers for WGA}

Measurement of the fluorescence emission spectra and excitation spectra were carried out in a Teflon-stoppered cuvette $(12.5 \mathrm{~mm}$ in width $\times 45 \mathrm{~mm}$ height) containing $3.0 \mathrm{~mL}$ of a sample. The slit width of the excitation and the emission was $5.0 \mathrm{~nm}$, and the scan speed was medium. The sensitivity was high, and the interval of sampling was $3.0 \mathrm{~nm}$. Emission spectra of WGA induced by excitation at $295 \mathrm{~nm}$ were uncorrected and were recorded with a Shimadzu RF-5300PC fluorescence spectrophotometer (Shimadzu Corp., Kyoto, Japan). The cuvette was mounted in a thermostated holder, and measurement was carried out at $4{ }^{\circ} \mathrm{C}$ in order to eliminate the effect of nonspecific binding on the spectra. The concentration of WGA was estimated to be $0.65 \mu \mathrm{M}$ using the absorption coefficient at $280 \mathrm{~nm}\left(\mathrm{E}_{280}{ }^{1 \%}=15.0\right.$ in $50 \mathrm{mM}$ Tris- $\mathrm{HCl}$ buffer, $\left.0.15 \mathrm{M} \mathrm{NaCl}, \mathrm{pH} 7.4\right)$ [35].

\section{Conclusions}

In conclusion, chloromethylstyrene was efficiently converted into the desired functional monomers by a combination of azide displacement, reduction and condensation with appropriate functional substrates. The assembly of the functional monomers by means of radical polymerization was performed using a GlcNAc monomer (NAG-Str) as a model monomer, and biological interactions between the polymers and a protein were demonstrated. This methodology can be applied to the preparation of various functional monomers and the corresponding polymers including the reversible deactivation radical polymerization (RDRPs) [41-44] and microwave-assisted polymer syntheses [45,46].

Supplementary Materials: The following are available online, Figure S1: ${ }^{1} \mathrm{H}-\mathrm{NMR}$ spectrum of DSL-Str 4, Figure S2: ${ }^{1} \mathrm{H}-\mathrm{NMR}$ spectrum of BTN-Str 5 , Figure S3: ${ }^{1} \mathrm{H}-\mathrm{NMR}$ spectrum of compound 7, Figure S4: ${ }^{1} \mathrm{H}-\mathrm{NMR}$ spectrum of compound 8, Figure S5: ${ }^{1} \mathrm{H}-\mathrm{NMR}$ spectrum of compound 9, Figure S6: ${ }^{1} \mathrm{H}-\mathrm{NMR}$ spectrum of NAG-Str 10.

Author Contributions: K.M. conceived and designed the experiments; R.H., T.K., T.M., K.H. and K.M. performed the experiments and analyzed the data; R.H. and K.M. contributed to preparation of the paper; and R.H. mainly wrote the paper. K.M. supervised the whole research. 
Funding: This work was partly supported by a grant-in-aid from Saitama Prefecture (K.M.) (Saitama Leading Edge Project).

Acknowledgments: We are grateful to AGC Seimi Chemical Co., Ltd. for providing chloromethylstyrene (CMS) used in this study.

Conflicts of Interest: The authors declare no conflict of interest associated with this manuscript.

\section{References}

1. Lee, Y.C. Biochemistry of carbohydrate-protein interaction. FASEB J. 1992, 6, 3193-3200. [CrossRef] [PubMed]

2. Lee, R.T.; Lee, Y.C. Affinity enhancement by multivalent lectin-carbohydrate interaction. Glycoconj. J. 2000, 17, 543-551. [CrossRef]

3. Chabre, Y.M.; Contino-Pepin, C.; Placide, V.; Shiao, T.C.; Roy, R. Expeditive synthesis of glycodendrimer scaffolds based on versatile TRIS and mannoside derivatives. J. Org. Chem. 2008, 73, 5602-5605. [CrossRef] [PubMed]

4. Niederhafner, P.; Sebestik, J.; Jezek, J. Glycopeptide dendrimers. J. Pept. Sci. 2008, 14, 2-43. [CrossRef] [PubMed]

5. Hatano, K.; Matsuoka, K.; Terunuma, D. Carbosilane glycodendrimers. Chem. Soc. Rev. 2013, 42, 4574-4598. [CrossRef] [PubMed]

6. Ladmiral, V.; Melia, E.; Haddleton, D.M. Synthetic glycopolymers: An overview. Eur. Polym. J. 2004, 40, 431-449. [CrossRef]

7. Varma, A.J.; Kennedy, J.F.; Galgali, P. Synthetic polymers functionalized by carbohydrates: A review. Carbohydr. Polym. 2004, 56, 429-445. [CrossRef]

8. Matsuoka, K.; Goshu, Y.; Takezawa, Y.; Mori, T.; Sakamoto, J.I.; Yamada, A.; Onaga, T.; Koyama, T.; Hatano, K.; Snyder, P.W.; et al. Practical synthesis of fully protected globotriaose and its glycopolymers. Carbohydr. Polym. 2007, 69, 326-335. [CrossRef]

9. Spain, S.G.; Cameron, N.R. A spoonful of sugar: The application of glycopolymers in therapeutics. Polym. Chem. 2011, 2, 60-68. [CrossRef]

10. Vazquez-Dorbatt, V.; Lee, J.; Lin, E.W.; Maynard, H.D. Synthesis of Glycopolymers by Controlled Radical Polymerization Techniques and Their Applications. Chembiochem 2012, 13, 2478-2487. [CrossRef] [PubMed]

11. Matsuoka, K.; Kurita, A.; Koyama, T.; Hatano, K. Use of chloromethylstyrene as a supporter for convenient preparation of carbohydrate monomer and glycopolymers. Carbohydr. Polym. 2014, 107, 209-213. [CrossRef] [PubMed]

12. Matsuoka, K.; Nishimura, S. Glycoconjugates.5. polymeric sugar ligands available for determining the binding-specificity of lectins. Macromolecules 1995, 28, 2961-2968. [CrossRef]

13. Matsuoka, K.; Takita, C.; Koyama, T.; Miyamoto, D.; Yingsakmongkon, S.; Hidari, K.; Jampangern, W.; Suzuki, T.; Suzuki, Y.; Hatano, K.; et al. Novel linear polymers bearing thiosialosides as pendant-type epitopes for influenza neuraminidase inhibitors. Bioorg. Med. Chem. Lett. 2007, 17, 3826-3830. [CrossRef] [PubMed]

14. Matsuoka, K.; Kohzu, T.; Hakumura, T.; Koyama, T.; Hatano, K.; Terunuma, D. Synthetic construction of a Le(x) determinant via gabriel amine synthesis and the glycopolymer involving highly clustered Le(x) residues. Tetrahedron Lett. 2009, 50, 2593-2596. [CrossRef]

15. Matsuoka, K.; Yamaguchi, H.; Koyama, T.; Hatano, K.; Terunuma, D. Synthetic construction of a fucosyl chitobiose as an allergen-associated carbohydrate epitope and the glycopolymer involving highly clustered trisaccharidic sequences. Tetrahedron Lett. 2010, 51, 2529-2532. [CrossRef]

16. Matsuoka, K.; Arai, H.; Oka, H.; Koyama, T.; Hatano, K. Synthetic Assembly of Bifluorescence-Labeled Glycopolymers as Substrates for Assaying $\alpha$-Amylase by Resonance Energy Transfer. ACS Macro Lett. 2012, 1, 266-269. [CrossRef]

17. Diamandis, E.P.; Christopoulos, T.K. The biotin (strept)avidin system-principles and applications in biotechnology. Clin. Chem. 1991, 37, 625-636. [PubMed]

18. Green, N.M. Avidin and streptavidin. Methods Enzymol. 1990, 184, 51-67. [PubMed]

19. Goldstein, I.J.; Poretz, R.D. Isolation and Chemical Properties of Lectins; Academic Press Inc.: Orlando, FL, USA, 1986.

20. Huisgen, R. 1,3-Dipolar Cycloadditions-Introduction, Survey, Mechanism; John Wiley: New York, NY, USA, 1984. 
21. Kolb, H.C.; Finn, M.G.; Sharpless, K.B. Click chemistry: Diverse chemical function from a few good reactions. J. Ger. Chem. Soc. 2001, 40, 2004-2021. [CrossRef]

22. Wu, P.; Fokin, V.V. Catalytic azide-alkyne cycloaddition: Reactivity and applications. Aldrichim. Acta 2007, 40, 7-17. [CrossRef]

23. Matsuoka, K.; Yamaguchi, H.; Kohzu, T.; Sakamoto, J.I.; Koyama, T.; Hatano, K.; Yamamoto, S.; Mori, T.; Hatanaka, K. Convenient assembly of trimeric Le(x) determinants using carbosilane scaffolds by means of Huisgen cycloaddition. Tetrahedron Lett. 2012, 53, 6793-6796. [CrossRef]

24. Zhou, W.J.; Kurth, M.J.; Hsieh, Y.L.; Krochta, J.M. Synthesis and characterization of new styrene main-chain polymer with pendant lactose moiety through urea linkage. Macromolecules 1999, 32, 5507-5513. [CrossRef]

25. Kim, Y.A.; Sharon, A.; Chu, C.K.; Rais, R.H.; Al Safarjalani, O.N.; Naguib, F.N.M.; el Kouni, M.H. Synthesis, biological evaluation and molecular modeling studies of $N$-6-benzyladenosine analogues as potential anti-toxoplasma agents. Biochem. Pharmacol. 2007, 73, 1558-1572. [CrossRef] [PubMed]

26. Shea, K.J.; Sasaki, D.Y.; Stoddard, G.J. Fluorescence probes for evaluating chain solvation in network polymers an analysis of the solvatochromic shift of the dansyl probe in macroporous styrene divinylbenzene and styrene diisopropenylbenzene copolymers. Macromolecules 1989, 22, 1722-1730. [CrossRef]

27. Montalbetti, C.; Falque, V. Amide bond formation and peptide coupling. Tetrahedron 2005, 61, 10827-10852. [CrossRef]

28. Kunishima, M.; Kawachi, C.; Hioki, K.; Terao, R.; Tani, S. Formation of carboxamides by direct condensation of carboxylic acids and amines in alcohols using a new alcohol- and water-soluble condensing agent: DMT-MM. Tetrahedron 2001, 57, 1551-1558. [CrossRef]

29. Nakabayashi, S.; Warren, C.D.; Jeanloz, R.W. A new procedure for the preparation of oligosaccharide oxazolines. Carbohydr. Res. 1986, 150, C7-C10. [CrossRef]

30. Nishimura, S.; Matsuoka, K.; Furuike, T.; Ishii, S. Synthetic glycoconjugates.2. normal-pentenyl glycosides as convenient mediators for the syntheses of new types of glycoprotein models. Macromolecules 1991, 24, 4236-4241. [CrossRef]

31. De Luca, L.; Giacomelli, G.; Masala, S.; Porcheddu, A. Trichloroisocyanuric/TEMPO oxidation of alcohols under mild conditions: A close investigation. J. Org. Chem. 2003, 68, 4999-5001. [CrossRef] [PubMed]

32. Zemplen, G.; Pascu, E. Übel die verseifung acetylierter zucker und verwandter substanzen. Berichte 1929, 62, 1613-1614.

33. Privat, J.-P.; Delmotte, F.; Mialonier, G.; Bouchard, P.; Monsigny, M. Fluorescence studies of saccharide binding to.wheat-germ agglutinin (lectin). Eur. J. Biochem. 1974, 47, 5-14. [CrossRef] [PubMed]

34. Bains, G.; Lee, R.T.; Lee, Y.C.; Freire, E. Microcalorimetric study of wheat-germ-agglutinin binding to n-acetylglucosamine and its oligomers. Biochemistry 1992, 31, 12624-12628. [CrossRef] [PubMed]

35. Lotan, R.; Sharon, N. Fluorescence of Wheat-Germ Agglutinin and of Its Complexes with Saccharides. Biochem. Biophys. Res. Commun. 1973, 55, 1340-1346. [CrossRef]

36. Schwefel, D.; Maierhofer, C.; Beck, J.G.; Seeberger, S.; Diederichs, K.; Moeller, H.M.; Welte, W.; Wittmann, V. Structural Basis of Multivalent Binding to Wheat Germ Agglutinin. J. Am. Chem. Soc. 2010, 132, 8704-8719. [CrossRef] [PubMed]

37. Kumari, A.; Koyama, T.; Hatano, K.; Matsuoka, K. Biological Evaluation of Multivalent-Type $\mathrm{N}$-Acetyl-D-Glucosamine (GlcNAc) Conjugates for Wheat Germ Agglutinin (WGA) by the Surface Plasmon Resonance (SPR) Method. SOJ Biochem. 2016, 2, 7. [CrossRef]

38. Lee, Y.C. Synthesis of some cluster glycosides suitable for attachment to proteins or solid matrices. Carbohydr. Res. 1978, 67, 509-514.

39. Lee, Y.C.; Townsend, R.R.; Hardy, M.R.; Lonngren, J.; Arnarp, J.; Haraldsson, M.; Lonn, H. Binding of synthetic oligosaccharides to the hepatic gal galnac lectin-dependence on fine-structural features. J. Biol. Chem. 1983, 258, 199-202. [PubMed]

40. Lundquist, J.J.; Toone, E.J. The cluster glycoside effect. Chem. Rev. 2002, 102, 555-578. [CrossRef] [PubMed]

41. Glasing, J.; Champagne, P.; Cunningham, M.F. Graft modification of chitosan, cellulose and alginate using reversible deactivation radical polymerization (RDRP). Curr. Opin. Green Sustain. Chem. 2016, 2, $15-21$. [CrossRef]

42. Ghadban, A.; Albertin, L. Synthesis of Glycopolymer Architectures by Reversible-Deactivation Radical Polymerization. Polymers 2013, 5, 431-526. [CrossRef]

43. Shipp, D.A. Reversible-Deactivation Radical Polymerizations. Polym. Rev. 2011, 51, 99-103. [CrossRef] 
44. Braunecker, W.A.; Matyjaszewski, K. Controlled/living radical polymerization: Features, developments, and perspectives. Prog. Polym. Sci. 2007, 32, 93-146. [CrossRef]

45. Hoogenboom, R.; Schubert, U.S. Microwave-assisted polymer synthesis: Recent developments in a rapidly expanding field of research. Macromol. Rapid Commun. 2007, 28, 368-386. [CrossRef]

46. Zetterlund, P.B.; Perrier, S. RAFT Polymerization under Microwave Irradiation: Toward Mechanistic Understanding. Macromolecules 2011, 44, 1340-1346. [CrossRef]

Sample Availability: Samples of the compounds 2, 4, 5 and 10 are available from the authors.

(C) 2018 by the authors. Licensee MDPI, Basel, Switzerland. This article is an open access article distributed under the terms and conditions of the Creative Commons Attribution (CC BY) license (http://creativecommons.org/licenses/by/4.0/). 